\title{
PEMBERDAYAAN MASYARAKAT MELALUI PEMANFAATAN LIMBAH JERAMI DAN SEKAM PADI MENJADI SUPERKARBON DI KECAMATAN MOYUDAN, SLEMAN
}

\author{
Fatwa Tentama * \\ Universitas Ahmad Dahlan \\ Yogyakarta
}

\section{Surahma Asti Mulasari Universitas Ahmad Dahlan Yogyakarta}

\section{Desta Risky Kusuma}

Universitas Ahmad Dahlan Yogyakarta

\begin{abstract}
COMMUNITY EMPOWER THROUGH UTILIZATION OF STRAW WASTE AND RICE HUSK BECOME SUPERCARBON IN MOYUDAN, SLEMAN. Karanganjir, Sejati Dukuh and Setran are three hamlets in the village Sumberarum. The livelihoods of the majority of the population worked as farmers. Each season rice harvest paddy lands in Karanganjir, Sejati Dukuh and Setran will produce abundant rice. Results of the rice harvest in the form of straw and rice husks were also plentiful. Rural farming communities Sumberarum have not been able to utilize the waste straw and rice husks are plentiful. This is due to the lack of awareness, knowledge, and skills for the use of waste straw and rice husks. Pollution of the environment requires a solution that is by utilizing the waste straw and rice husks into supercarbon as kerosene and gas for household and economic value. The program will work closely with youth organizations and farmers' groups in Karanganjir, Sejati Dukuh and Setran, Co-operative of Sumberarum village, Co-operative of Universitas Ahmad Dahlan (UAD), and Department of Industry Trade and Cooperatives of Sleman. This program is conducted by lecturers and UAD students of Community Service Program (KKN) divided into five major themes: 1) Entrepreneurship; 2) Making supercarbon from agricultural waste; 3) Utilization supercarbon as an alternative fuel; 4) Motivating supercarbon entrepreneurship; 5) The establishment and development of business units supercarbon.
\end{abstract}

* Corresponding Author: Fakultas Psikologi Universitas Ahmad Dahlan Yogyakarta; Jalan Kapas No. 09, Umbulharjo, Yogyakarta 55166; Email: fatwa.tentama@ psy.uad.ac.id

\section{PENDAHULUAN}

Kabupaten Sleman merupakan wilayah dengan luas lahan pertanian terbesar di Propinsi Daerah Istimewa Yogyakarta dibandingkan dengan Kabupaten Bantul, Kulon Progo, Gunung Kidul, dan Yogyakarta. Total luas lahan pertanian di wilayah Sleman adalah 39.462 (Dinas Pertanian Kab./Kota, Provinsi D.I. Yogyakarta, 2010). Desa Sumberarum terletak di Kecamatan Moyudan, 
Kabupaten Sleman. Dilihat dari topografi, ketinggian wilayah Sumberarum berada pada $125 \mathrm{~m}$ ketinggian dari permukaan air laut dengan curah hujan rata-rata $2225 \mathrm{~mm} /$ tahun, serta suhu rata-rata per tahun adalah 17-41 ${ }^{\circ} \mathrm{C}$. Dengan kondisi iklim tersebut maka banyak ditemukan lahan-lahan persawahan di hampir seluruh bagian Desa Sumberarum. Hal ini berarti bahwa penggunaan lahan terbesar adalah sektor pertanian dan sebagian besar pekerjaan masyarakat adalah bertani/petani. Setiap musim bertanam dan musim panen padi tentu saja lahan-lahan pertanian akan menghasilkan padi kering giling y ang berlimpah.

Hasil panen padi yang berlimpah di Desa Sumberarum tidak hanya mendatangkan keuntungan bagi masyarakatnya, namun juga menjadi permasalahan karena adanya sisa hasil panen padi berupa jerami serta sekam padi yang banyak menumpuk di penggilingan, di pinggir-pinggir sawah, di sekitar sungai-sungai di desa Sumberarum. Limbah jerami dan sekam padi merupakan sampah pertanian, jenisnya adalah sampah organik. Sampah ini apabila dalam jumlah yang besar dan tidak diolah akan mengakibatkan permasalahan lingkungan sekitar (Nugroho, 2013). Petani hanya membiarkan limbah yang dihasilkan oleh panen mereka, terkadang juga hanya dibakar sehingga menimbulkan polusi udara. Pembakaran langsung akan menghasilkan pembakaran tidak sempurna yang menghasilkan asap yang berbahaya bagi kesehatan (Fuhaid \& Finahari, 2008). Fenomena tersebut menunjukkan tidak adanya kesadaran akan pentingnya lingkungan, minimnya ilmu dan pengetahuan para petani dan pada akhirnya mempengaruhi kreativitas dan produktivitas para petani-petani tersebut karena apabila diolah dengan teknologi yang tepat guna di bidang lingkungan, jerami dan sekam padi memiliki banyak sekali manfaat. Petani tidak menyadari bahwa semakin tinggi produksi di lahan pertaniannya maka limbahnya semakin banyak sehingga diperlukan pemanfaatan limbah-limbah tersebut.

Masyarakat petani di Dusun Karanganjir, Dusun Sejati Dukuh dan Dusun Setran belum mampu memanfaatkan limbah sekam padi dan jerami yang berlimpah tersebut. Hal ini dikarenakan minimnya kesadaran, pengetahuan, dan ketrampilan untuk memanfaatkan limbah jerami dan sekam padi. Dampak yang muncul adalah pencemaran lingkungan karena limbah jerami dan sekam padi yang semakin meningkat di Dusun Karanganjir, Dusun Sejati Dukuh dan Dusun Setran. Pencemaran lingkungan tersebut memerlukan sebuah solusi yaitu dengan memanfaatkan limbah jerami dan sekam padi menjadi superkarbon dan bernilai ekonomi. 
Limbah sekam padi dan jerami diolah menjadi superkarbon dengan peralatan yang sederhana dan dapat dibentuk sesuai kebutuhan (Soeyanto, 1982). Superkarbon adalah bahan bakar karbon dalam bentuk briket yang diproduksi dari limbah bahan organik maupun turunannya yang masih mengandung sejumlah energi. Limbah tersebut diolah sehingga dapat digunakan sebagai sember energi untuk keperluan rumah tangga maupun industri yang dapat diperbaharui (Kurniawan \& Marsono, 2008). Superkarbon dapat dimanfaatkan sebagi bahan bakar pengganti di dalam rumah tangga (Asmara \& Igo, 2007). Selain itu superkarbon juga merupakan bahan bakar padat yang mengandung karbon, mempunyai nilai kalori yang tinggi, dan dapat menyala dalam waktu yang lama (Seran, 1990). Hambali, Mujdalipah, Tambunan, Pattiwiri, dan Hendroko (2008) menambahkan bahwa bahan bakar superkarbon lebih ramah lingkungan karena tidak mengandung zat beracun yang dapat mencemari udara.

Andry (2000) mengungkapkan bahwa alat yang digunakan untuk pembuatan superkarbon cukup sederhana dan bahan bakunya sangat murah, bahkan tidak perlu membeli karena berasal dari sampah, daun-daun kering, limbah pertanian yang sudah berguna lagi. Bahan baku untuk pembuatan arang umumnya telah tersedia disekitar kita. Superkarbon dalam penggunaannya menggunakan tungku yang relatif kecil dibandingkan dengan tungku yang lainnya

Bentuk kegiatan yang akan dilakukan berupa pelatihan dan pendampingan pembuatan superkarbon dengan memanfaatkan jerami dan sekam padi dilakukan oleh dosen UAD dan mahasiswa KKN dengan melibatkan masyarakat dusun sumberarum. Harapannya sekam padi dan jerami sisa panen dapat bermanfaat menjadi bahan yang bermanfaat bagi masyarakat yaitu superkarbon dan bernilai ekonomi. Tujuan dengan diadakannya kegiatan KKN-PPM ini, adalah memberikan solusi untuk mengatasi permasalahan pencemaran limbah jerami dan sekam padi yaitu pemberdayaan masyarakat dalam memanfaatkan jerami dan sekam padi, menghasilkan bahan bakar alternatif superkarbon dari limbah pertanian, meningkatkan taraf ekonomi masyarakat melalui cara pemberdayaan masyarakat untuk industri rumah tangga "superkarbon", penghematan bahan bakar minyak dan gas, meningkatkan kemampuan dan ketrampilan kewirausahaan, meningkatkan motivasi berwirausaha, serta meningkatkan kepedulian dan empati mahasiswa Universitas Ahmad Dahlan terhadap permasalahan lingkungan dan masyarakat ekonomi lemah, khususnya masyarakat di Dusun Karanganjir, Dusun Sejati Dukuh dan Dusun Setran kecamatan Moyudan Kabupaten Sleman. 


\title{
METODE PELAKSANAAN
}

Kegiatan dilaksanakan di Desa Sumberarum Kecamatan Moyudan sleman Yogyakarta oleh 27 orang mahasiswa KKN UAD. Pelaksanaan kegiatan KKN PPM akan berlangsung selama satu bulan. Kelompok sasarannya adalah warga dusun Karanganjir, Dusun Sejati Dukuh dan Dusun Setran. Pelatihan dan pendampingan ini akan dilakukan oleh dosen UAD dan mahasiswa KKN. Pelatihan dan pendampingan ini akan dilakukan oleh dosen UAD dan mahasiswa KKN bekerjasama dengan organisasi pemuda Dusun Karanganjir, Dusun Sejati Dukuh dan Dusun Setran, kelompok tani di Dusun Karanganjir, Dusun Sejati Dukuh dan Dusun Setran, koperasi Desa Sumberarum, Koperasi Universitas Ahmad Dahlan, Dinas Pertanian Kabupaten Sleman serta Dinas Perindustrian Perdagangan dan Koperasi Kabupaten Sleman yang nantinya akan dapat membantu dalam kelancaran proses pelaksanaan program pelatihan bahkan sampai kepada pemasaran untuk meningkatkan perekonomian masyarakat setempat.

Potensi dan peluang yang mendukung keberhasilan program di wilayah tersebut adalah tersedianya bahan baku (jerami dan sekam padi) yang melimpah, kelembagaan organisasi masyarakat yang kuat, di tingkat kecamatan memiliki koperasi usaha tani, pemerintah daerah memiliki komitmen yang kuat untuk memajukan kesejahteraan warganya.

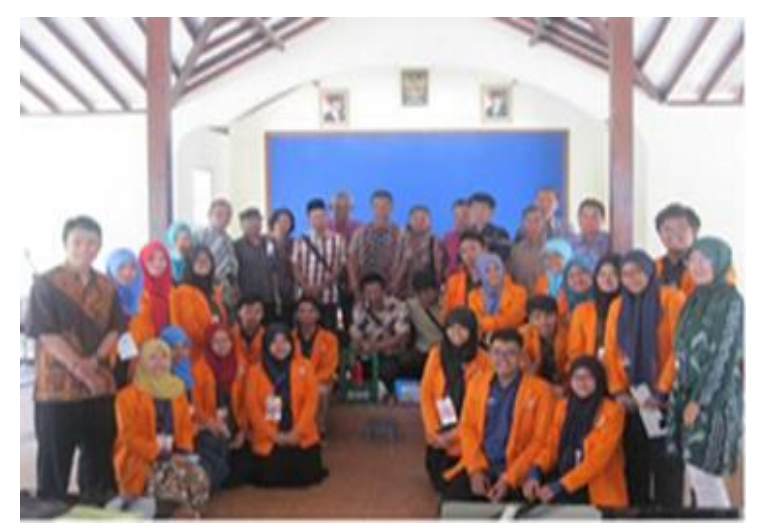

Gambar 1. Tim pengabdian masyarakat KKN-PPM

\begin{abstract}
Alat dan Bahan
Bahan utama yang digunakan dalam pembuatan superkarbon adalah sekam padi, bahan perekat tepung tapioka, dan air panas. Alat yang digunakan adalah paralon/seng dengan diameter $10 \mathrm{~cm}$ dan tinggi $7 \mathrm{~cm}$, mesin cetak superkarbon, panci, air, dan kompor.
\end{abstract}




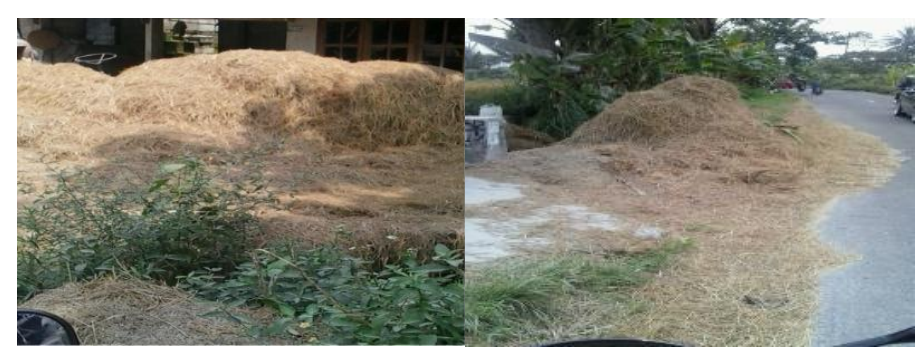

Gambar 2. Jerami dan Sekam Padi

Penggunaan perekat tepung tapioka karena daya lengket yang dihasilkan lebih kuat. Schuchart et al (1996) mengungkapkan bahwa pembuatan briket dengan penggunaan bahan perekat akan lebih baik hasilnya jika dibandingkan tanpa menggunakan bahan perekat. Disamping meningkatkan nilai bakar dari bioarang, kekuatan briket arang dari tekanan luar juga lebih baik (tidak mudah pecah).

\section{Pelaksanaan Pembuatan Superkarbon}

Metode yang digunakan dalam pembuatan superkarbon oleh masyarakat didampingi mahasiswa KKN-PPM dan dosen UAD adalah meliputi penyuluhan dan pendampingan dalam membuat superkarbon yaitu penyuluhan penanggulangan pencemaran limbah pertanian. Kemudian penyuluhan dan pelatihan pembuatan superkarbon dari limbah jerami. Selanjutnya, penyuluhan dan pelatihan pembuatan superkarbon dari limbah sekam. Kemudian, penyuluhan dan pelatihan pemanfaatan superkarbon sebagai bahan bakar alternatif pengganti minyak tanah dan gas dalam rumah tangga. Kemudian penyuluhan dan pelatihan kewirausahaan dengan tema "berwirausaha superkarbon" bagi masyarakat kelompok tani dan pemuda. Kemudian penyuluhan dan pelatihan "meningkatkan motivasi wirausaha" untuk memanfaatkan peluang usaha superkarbon bagi para pemuda. Terakhir adalah pembentukan dan pengembangan unit usaha "superkarbon" di Dusun Karanganjir, Sejati Dukuh dan Setran

\section{HASIL DAN PEMBAHASAN}

Aktivitas penyuluhan penanggulangan bahaya limbah sekam padi ini dilatarbelakangi oleh banyaknya sisa hasil pertanian yang banyak ditemukan di wilayah Desa Sumberarum Moyudan Sleman. Berdasarkan hasil wawancara dengan beberapa petani di desa tersebut banyak limbah hasil pertanian yang hanya dibuang (dibakar) begitu saja dan hanya dimanfaatkan sebatas untuk membakar batu bata, abu gosok dan digiling menjadi katul/dedak. Dalam hal pembakaran limbah tersebut memberikan dampak yang buruk terhadap kesehatan lingkungan. Padahal limbah hasil pertanian ini jika dikelola dengan benar bisa mengurangi 
dampak buruk terhadap lingkungan dan bahkan bisa memberikan manfaat secara ekonomis. Oleh karenanya, masyarakat di Desa Sumberarum perlu diberikan penyuluhan mengenai penanggulangan bahaya limbah pertanian, guna menanamkan kesadaran kesehatan lingkungan kepada warga desa.

Tahapan selanjutnya setelah warga Desa Sumberarum memahami bahaya limbah pertanian adalah memberikan penyuluhan dan praktik bagaimana memanfaatkan limbah tersebut menjadi sebuah produk yang mempunyai nilai jual. Pada aktivitas ini penyuluhan dilakukan oleh Dosen Fakultas Kesehatan Masyarakat dan tim mahasiswa KKN. Penyuluhan dilakukan tidak hanya secara teori tetapi juga secara praktik, warga desa dibekali kemampuan secara prosedural dan teknis dalam mengolah limbah sekam padi menjadi superkarbon (bahan bakar alternatif). Selain itu untuk menunjang keberlanjutan aktivitas ini, warga desa difasilitasi dengan alat cetak superkarbon, kompor superkarbon beserta alat pengemasannya. Hasil dari aktivitas ini adalah warga desa mampu membuat superkarbon yang memenuhi standar mutu.

Produk superkarbon ini banyak memberikan manfaat sebagai bahan bakar alternatif baik dalam rumah tangga, perdagangan, dan industri. Dalam penerapannya warga desa dapat menggunakan tungku atau kompor khusus superkarbon yang difasilitasi oleh tim pengusul. Namun sebelumnya warga desa diberikan bagaimana cara menggunakan superkarbon tersebut sebagai bahan bakar alternatif. Banyak kelebihan, yang diberikan superkarbon diantaranya, panas pembakaran lebih tinggi, masa bakar lebih tahan lama, asap yang dikeluarkan tidak mencemari lingkungan, dan praktis relatif aman.

Kondisi tersebut memungkinkan produk superkarbon bisa dikembangkan ke sektor bisnis. Dalam pengembangannya tersebut diperlukan pelatihan kewirausahaan yang berdampak pada meningkatnya pengetahuan dan keterampilan memanfaatkan limbah pertanian yang berdampak meningkatnya motivasi berwirausaha. Pelatihan kewirausahaan ini memberikan kemampuan kepada masyarakat bagaimana mengindra peluang bisnis superkarbon, bagaimana masyarakat berinisiatif, berinovasi dan kreatif, mampu bekerja keras dan berani mengambil resiko.

Perlu dibentuk unit usaha yang mewadahi beberapa warga didalam mengembangkan wirausaha superkarbon untuk lebih merealisasikan usaha superkarbon di Desa Sumberarum. Unit usaha ini didampingi oleh tim pengusul dan mahasiswa KKN dalam menjalankan manajemen usaha superkarbon, diantaranya adalah teknik pengemasan, pemasaran produk, dan pencatatan administrasi keuangan. Sebagai contoh pada pengemasan produk superkarbon yang 
sudah dihasilkan perlu dikemas dengan baik (diberikan label dan merek) supaya lebih mempunyai daya tarik dalam segi kemasan.

Selain didampingi oleh tim dan mahasiswa KKN dalam kegiatan ini juga mendatangkan pakar perindustrian dan praktisi pengusaha superkarbon, yang diharapkan dapat menambah pengetahuan dan pengalaman anggota unit usaha.

\section{Keberlanjutan Program}

Keberlanjutan program pemberdayaan masyarakat ini berlangsung selama tiga tahun disajikan dalam bentuk bagan dapat dilihat pada Gambar 3.

\section{TAHUN PERTAMA}

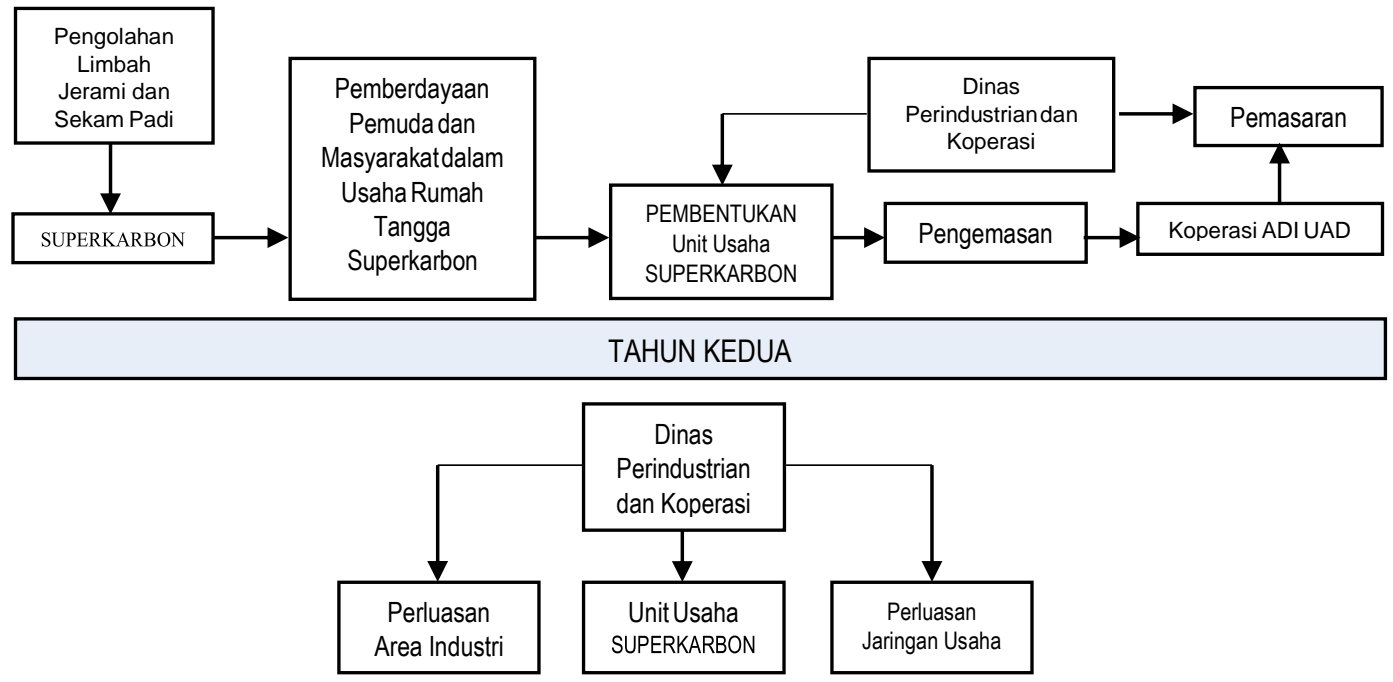

TAHUN KETIGA

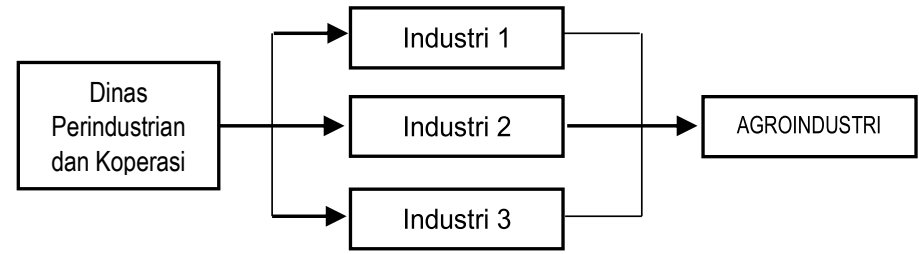

Gambar 3. Bagan Keberlanjutan Program

\section{SIMPULAN}

Hasil yang telah dicapai pada kegiatan ini adalah masyarakat sasaran sudah memiliki kesadaran dan pemahaman mengenai bahaya pencemaran limbah pertanian berupa jerami dan sekam padi dan cara menanggulanginya yaitu dengan diolah menjadi superkarbon yang bermanfaat sebagai alternatif bahan bakar untuk 
memasak serta mempunyai nilai ekonomi. Masyarakat lebih memahami bagaimana cara membuat superkarbon yang memiliki standar mutu dan cara pengemasan yang aman sehingga dapat terbentuk unit usaha superkarbon dan masyarakat memiliki pengetahuan dan keterampilan untuk mengembangkan unit usaha tersebut. Perlu dilakukan pendampingan dan peningkatan motivasi berwirausaha pada petani, perluasan cakupan kegiatan pelatihan pemanfaatan limbah jerami dan sekam padi, pendampingan manajemen usaha superkarbon yang berkelanjutan, serta perluasan jaringan usaha superkarbon dengan unit-unit usaha yang lain sehingga menjadi industri yang lebih besar.

\section{REFERENSI}

Andry, H. U. (2000). Aneka tungku sederhana. Yogyakarta: Penebar Swadaya.

Asmara, A. I. (2007). Kompor briket batu bara. Bandung: Titian Ilmu.

Dinas Pertanian Kab./Kota, Provinsi D.I. Yogyakarta. (2010). Kecamatan Moyudan. Retrieved November 17, 2016, from website http://moyudankec.slemankab.go.id/demografis.

126 Fuhaid, N., \& Finahari, N. (2008). Aplikasi bahan bakar padat berbahan dasar sekam dan jerami sebagai bahan bakar alternatif bagi petani. Jurnal Widya Teknika, 16(1), 32-37.

Hambali, E., Mujdalipah, S., Tambunan, A. H., Pattiwiri, A. W., \& Hendroko, R. (2007). Teknologi bioenergi. Jakarta: AgroMedia Pustaka.

Hambali, E., Mujdalipah, S., Tambunan, A. H., Pattiwiri, A. W., \& Hendroko, R. (2008). Teknologi bioenergi (Edisi revisi). Jakarta: AgroMedia Pustaka.

Kurniawan \& Marsono. (2008). Superkarbon: Bahan bakar alternatif pengganti minyak tanah dan gas. Jakarta: Penerbit Penebar Swadaya.

Nugroho, P. (2013). Panduan membuat pupuk kompos cair. Yogyakarta: Pustaka Baru Press.

Schuchart, F., Wulfert, K., Darmoko, Darmosarkoro, W., \& Sutara, E. S. (1996). Pedoman teknis pembuatan briket bioarang. Medan: Balai Penelitian dan Pengembangan Kehutanan, Dephut Sumatera Utara.

Seran, J. B. (1990). Bioarang untuk memasak, Edisi II. Yogyakarta: Liberti.

Soeyanto, T. (1982). Cara membuat sampah jadi arang dan kompos. Jakarta: Yudhistira. 